\title{
A Direct Comparison of the Single-Channel Properties of Synaptic and Extrasynaptic NMDA Receptors
}

\author{
Beverley A. Clark, Mark Farrant, and Stuart G. Cull-Candy \\ Department of Pharmacology, University College London, London WC1E 6BT, United Kingdom
}

The assumption that synaptic and extrasynaptic glutamate receptors are similar underpins many studies that have sought to relate the behavior of channels in excised patches to the macroscopic properties of the EPSC. We have examined this issue for NMDA receptors in cerebellar granule cells, the small size of which allows the opening of individual synaptic NMDA channels to be resolved directly. We have used whole-cell patchclamp recordings to determine the conductance and open time of NMDA channels activated during the EPSC and used cellattached and outside-out recordings to examine NMDA receptors in somatic membrane. Conductance and open time of synaptic channels were indistinguishable from those of extra- synaptic channels in cell-attached patches. However, the channel conductance in outside-out patches was $20 \%$ lower than in cell-attached recordings. This change was partially reduced by dantrolene and phalloidin, suggesting that it may involve depolymerization of actin following $\mathrm{Ca}^{2+}$ release from intracellular stores. Our results demonstrate that synaptic and extrasynaptic NMDA receptors have similar microscopic properties. However, NMDA channel conductance is reduced following the formation of an outside-out patch.

Key words: cerebellum; granule cell; patch clamp; NMDA; single channel; synaptic; extrasynaptic
NMDA receptors participate in excitatory neurotransmission and play a key role in several forms of synaptic plasticity. With the aim of understanding how the behavior of these receptors gives rise to the unique features of the NMDA component of the EPSC, their functional properties have been studied widely at the singlechannel level (Nowak et al., 1984; Johnson and Ascher, 1987; Lester et al., 1990; Howe et al., 1991; Edmonds and Colquhoun, 1992; Gibb and Colquhoun, 1992) (for review, see Edmonds et al., 1995). Normally, such recordings have been made from isolated patches of somatic membrane, because the postsynaptic membrane of central neurons is inaccessible to patch electrodes. However, it is possible that receptor properties are not identical in all regions of the cell. For example, many neurons contain mRNAs for several types of NMDA receptor subunits (Akazawa et al., 1994; Monyer et al., 1994; Watanabe et al., 1994), different combinations of which give rise to recombinant receptors with diverse properties (for review, see McBain and Mayer, 1994). Thus, a differential subcellular distribution of these subunits (Miyashiro et al., 1994; Ehlers et al., 1995) could lead to the expression of functionally distinct receptors within different regions of the neuronal membrane. Moreover, the association of NMDA receptors with cytoskeletal elements (Rosenmund and Westbrook, 1993b; Paoletti and Ascher, 1994) and synaptic proteins (Kornau et al., 1995; Niethammer et al., 1996) could influence their properties differently, depending on their location. The occurrence of several

\footnotetext{
Received July 8, 1996; revised Sept. 30, 1996; accepted Oct. 18, 1996.

This work was supported by the Wellcome Trust, the Medical Research Council, and an International Scholars Award from The Howard Hughes Medical Institute to S.G.C.-C. We are grateful to David Colquhoun and Stephen Traynelis for providing software and to Brian Edmonds, Dirk Feldmeyer, Akiko Momiyama, and Angus Silver for discussion and comments on this manuscript.

Correspondence should be addressed to Dr. Mark Farrant, Department of Pharmacology, University College London, Gower Street, London WC1E 6BT, UK.

Dr. Clark's present address: Laboratoire de Neurobiologie, Ecole Normale Supérieure, Centre National de la Recherche Scientifique, Unité de Recherche Associée 1857, 46 Rue d’Ulm, 75230 Paris, Cedex 05, France.

Copyright (C) 1996 Society for Neuroscience $0270-6474 / 96 / 170107-10 \$ 05.00 / 0$
}

distinct types of native NMDA receptors has been indicated by patch-clamp studies (for review, see Cull-Candy et al., 1995), and recently it has been shown that individual neurons can express more than one type of NMDA receptor, detected as discrete populations of channel amplitudes within the same patch (Farrant et al., 1994; Momiyama et al., 1996).

It is usually difficult to resolve individual synaptic NMDA channel openings during EPSCs because of the noise associated with whole-cell recording and problems of voltage-clamp control at synapses remote from the soma. However, in cerebellar granule cells, the small size of which affords voltage-clamp recordings of unusually high resolution, synaptic NMDA openings can be detected as clear current steps in the tail of spontaneous miniature EPSCs (Silver et al., 1992). We have taken advantage of this resolution to record the opening of single NMDA channels during EPSCs evoked at the mossy fiber-granule cell synapse and have compared the properties of these channels with those of extrasynaptic channels recorded both in cell-attached and outside-out patch configurations.

\section{MATERIALS AND METHODS}

Tissue and preparation. Recordings were made from granule cells of the cerebellum in parasagittal slices $(150-200 \mu \mathrm{m})$ obtained from 12- to 13-d-old (P12-P13) Sprague Dawley rats. Cerebellar slices were prepared and maintained as previously described (Farrant and Cull-Candy, 1991; Farrant et al., 1994).

Solutions and drugs. During recording, slices were perfused continuously with a solution containing (in $\mathrm{mM}$ ): $\mathrm{NaCl} 125, \mathrm{KCl} 2.5, \mathrm{CaCl}_{2} 1$, $\mathrm{NaHCO}_{3} 26, \mathrm{NaH}_{2} \mathrm{PO}_{4} 1.25$, and glucose $25(\mathrm{pH} 7.4$ when bubbled with $\left.95 \% \mathrm{O}_{2} / 5 \% \mathrm{CO}_{2}\right)$. The free $\mathrm{Ca}^{2+}$ concentration in this solution $(0.84 \pm$ $0.01 \mathrm{~mm}, n=3$ ) was determined by using a calcium-sensitive electrode (Orion Research, Boston, MA). Bicuculline methobromide $(10 \mu \mathrm{M})$, glycine $(3 \mu \mathrm{M})$, and strychnine hydrochloride $(300 \mathrm{nM})$ were added to this solution during the recording of evoked EPSCs. For cell-attached recording, the pipette was filled with this solution plus glutamate (1 $\mu \mathrm{M})$ and 6-cyano-7-dinotroquinoxaline-2,3-dione (CNQX; $5 \mu \mathrm{M})$. Any change in the $\mathrm{Ca}^{2+}$ buffering in this unbubbled solution could cause a change in the free $\mathrm{Ca}^{2+}$ concentration and affect the NMDA single- 
Figure 1. Prolonged NMDA channel activity during evoked EPSCs. $A$, An individual EPSC recorded from a cerebellar granule cell (P12) at a holding potential of $-90 \mathrm{mV}$. Currents were evoked by stimulation $(16 \mathrm{~V}, 16 \mu \mathrm{sec}$, $0.25 \mathrm{~Hz}$ ) delivered through a patch pipette placed in the granule cell layer. A fast non-NMDA receptor-mediated component of the EPSC is followed by a noisy NMDA receptor-mediated component. $B$, Average of 50 EPSCs from the same cell as $A$ (control), superimposed on the average of $50 \mathrm{EP}$ SCs recorded in the presence of AP5 $(20 \mu \mathrm{M}) . C$, Average of 50 control EPSCs (same as $B$ ) showing more clearly the slow time course of the second component of the synaptic current (the initial non-NMDA receptor-mediated component is truncated in this display). In this cell the decay of the slow component, beginning from the clear inflexion in the current decay after the initial non-NMDA receptor-mediated component, could be fit with two exponentials having time constants of 23.1 msec $(71.1 \%)$ and $222.0 \mathrm{msec}$ (solid line). For display, the currents were digitized at $5 \mathrm{kHz}$ after filtering at 1 $\mathrm{kHz}$ (8-pole Bessel, -3 dB).
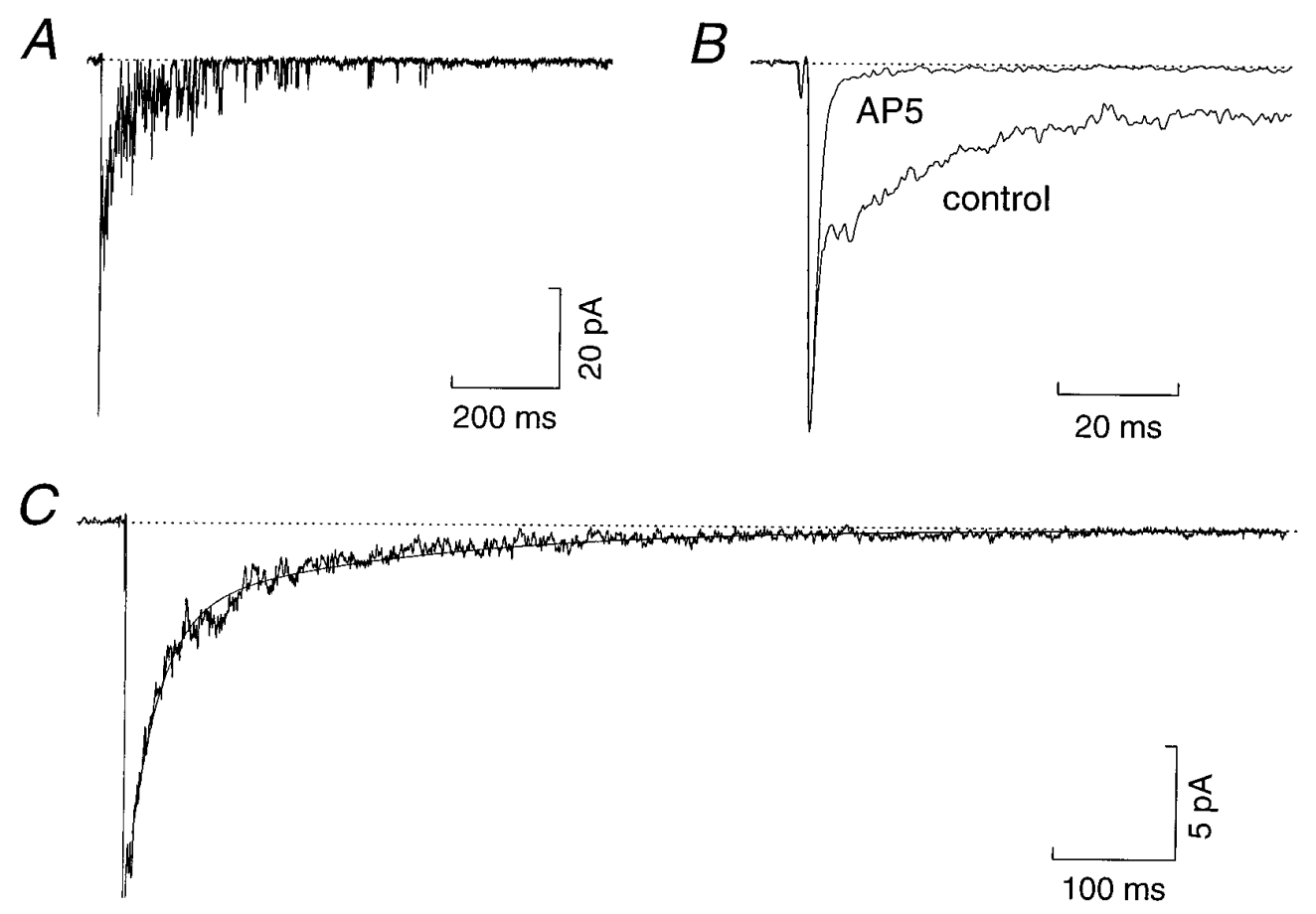

channel conductance (Gibb and Colquhoun, 1992; Jahr and Stevens, 1993; Tsuzuki et al., 1994). However, under semisealed conditions designed to mimic the situation in a patch pipette, the free $\mathrm{Ca}^{2+}$ concentration and $\mathrm{pH}$ of this solution remained stable for $>1 \mathrm{hr}$. For whole-cell and outside-out patch recording, the pipette solution (intracellular solution) contained (in mM): $\mathrm{CsF} 110, \mathrm{CsCl} 30, \mathrm{NaCl} 4, \mathrm{CaCl}_{2}$ 0.5, HEPES 10, EGTA 5, and Mg-ATP 2, adjusted to pH 7.3 with $\mathrm{CsOH}$. In some experiments EGTA was replaced with bis- $(o-$ aminophenoxy)- $N, N, N^{\prime}, N^{\prime}$-tetraacetic acid (BAPTA; $10 \mathrm{~mm}$ plus 0.1 $\mathrm{mM} \mathrm{Ca}{ }^{2+}$ ), and in others this BAPTA internal was supplemented with $20 \mu \mathrm{M}$ dantrolene or $1 \mu \mathrm{M}$ phalloidin. Chemicals were obtained from BDH (Poole, UK), Research Biochemicals (Natick, MA), Sigma (Poole, UK), and Tocris Cookson (Bristol, UK).

Current recording. Whole-cell, cell-attached, and outside-out patch recordings (Hamill et al., 1981) were made at room temperature $\left(22-25^{\circ} \mathrm{C}\right)$ from granule cells on the surface of the slice. Cells were viewed with Nomarski differential interference optics (Axioscop FS, Zeiss, Welwyn Garden City, UK; $40 \times$ water immersion objective; total magnification, $320-1000 \times$ ). Recordings were made with an Axopatch-1D (Axon Instruments, Foster City, CA) and an L/M-EPC 7 (List, Darmstadt, Germany) patch-clamp amplifier. Patch pipettes were pulled from thick-walled glass (GC150F-7.5, Clark Electromedical, Pangbourne, UK), coated with SYLGARD 184 resin (Dow Corning, Midland, MI), and fire-polished to a resistance of 8-12 $\mathrm{M} \Omega$ when filled with intracellular solution. For dual whole-cell and cell-attached recording, gigaohm seals were established with both electrodes before rupturing the patch of membrane beneath the electrode containing intracellular solution. The command potential for the cell-attached electrode was set to $0 \mathrm{mV}$ and that for the whole-cell electrode to $-70 \mathrm{mV}$. Mossy fibers were stimulated via a $2 \mathrm{M} \mathrm{NaCl}$-filled electrode placed 20-200 $\mu \mathrm{m}$ from the soma of the recorded cell; a 10-30 $\mathrm{V}$ pulse of $15-25 \mu \mathrm{sec}$ duration was delivered at $0.1-0.25 \mathrm{~Hz}$ (Neurolog DS2, Digitimer Limited, Welwyn Garden City, UK).

Data acquisition and analysis. Current data were recorded on FM tape (Store 4, Racal, UK; band width DC to $1.25-5 \mathrm{kHz},-3 \mathrm{~dB}$ ) or on digital audio tape (DTR-1204, BioLogic, Claix, France; DC to $20 \mathrm{kHz}$ ). Currents were replayed from tape, filtered at $2 \mathrm{kHz}(-3 \mathrm{~dB}$, 8-pole Bessel type filter), and digitized at $10 \mathrm{kHz}$ (Digidata 1200, Axon Instruments). All-point amplitude histograms were constructed from selected portions within the tail of EPSCs up to $300 \mathrm{msec}$ from the onset of the synaptic current (pCLAMP 6.0.1, Fetchan, Axon Instruments). In addition, singlechannel currents were analyzed by the method of time course fitting (EKDIST; Colquhoun and Sigworth, 1995). Currents were replayed from tape, filtered at 1 or $2 \mathrm{kHz}(-3 \mathrm{~dB}, 8$-pole Bessel type filter), and digitized at $20 \mathrm{kHz}$ (CED 1401+ interface; Cambridge Electronic Design, Cambridge, UK). Individual openings were fit by the step-response function of the recording system; only openings longer than two filter rise times (reaching $98.8 \%$ of their full amplitude) were included. The mean amplitude levels of single-channel currents were determined from fits of one or two Gaussian distributions to the cursor-fit amplitudes. Channel open times are given as mean values for all openings or the time constants of exponential functions fit to the distributions of open times. Distributions were fit by the method of maximum likelihood (Colquhoun and Sigworth, 1995). The generalized Henderson equation (Barry and Lynch, 1991) (Axoscope1, Axon Instruments) was used to calculate the theoretical liquid junction potential between the internal and external solutions (6.9 $\mathrm{mV}$ ). No correction was applied, because in all cases slope conductance was measured, and for each cell or patch the reversal potential of the NMDA channel currents $\left(E_{\text {rev }}\right)$ was determined by extrapolation of the all-point current-voltage relationship. Chord conductance $\left(\gamma_{\text {chord }}\right)$ from time course fitting at single potentials was determined according to $\gamma_{\text {chord }}$ $=i /\left(V_{\mathrm{cmd}}-E_{\mathrm{rev}}\right)$, in which $i$ is the observed single-channel current and $V_{\text {cmd }}$ the command voltage. All values are reported as mean $\pm \operatorname{SEM}(n=$ number of cells or patches). Differences between groups were tested by a randomization test (RANTEST; Colquhoun, 1971) and were considered significant at $p<0.05$.

\section{RESULTS}

\section{Resolution of synaptic NMDA channel openings}

Whole-cell recordings of synaptic currents were made from 44 cerebellar granule cells in slices obtained from 12- to 13-d-old rats. We chose to examine evoked EPSCs, because this allowed unambiguous identification of synaptic events. Figure $1 A$ shows representative EPSCs recorded from a granule cell in response to local stimulation of a mossy fiber input. The bath solution routinely contained glycine to facilitate NMDA receptor activation (Johnson and Ascher, 1987), the glycine receptor antagonist strychnine, and the $\mathrm{GABA}_{\mathrm{A}}$ antagonist bicuculline methobromide to block inhibitory postsynaptic currents arising from Golgi cells (Kaneda et al., 1995). Under these conditions, evoked currents had a rapidly rising and decaying initial component, followed by a slowly decaying noisy tail (Fig. $1 A, C$ ). As expected, these two components were differentially sensitive to glutamate receptor 


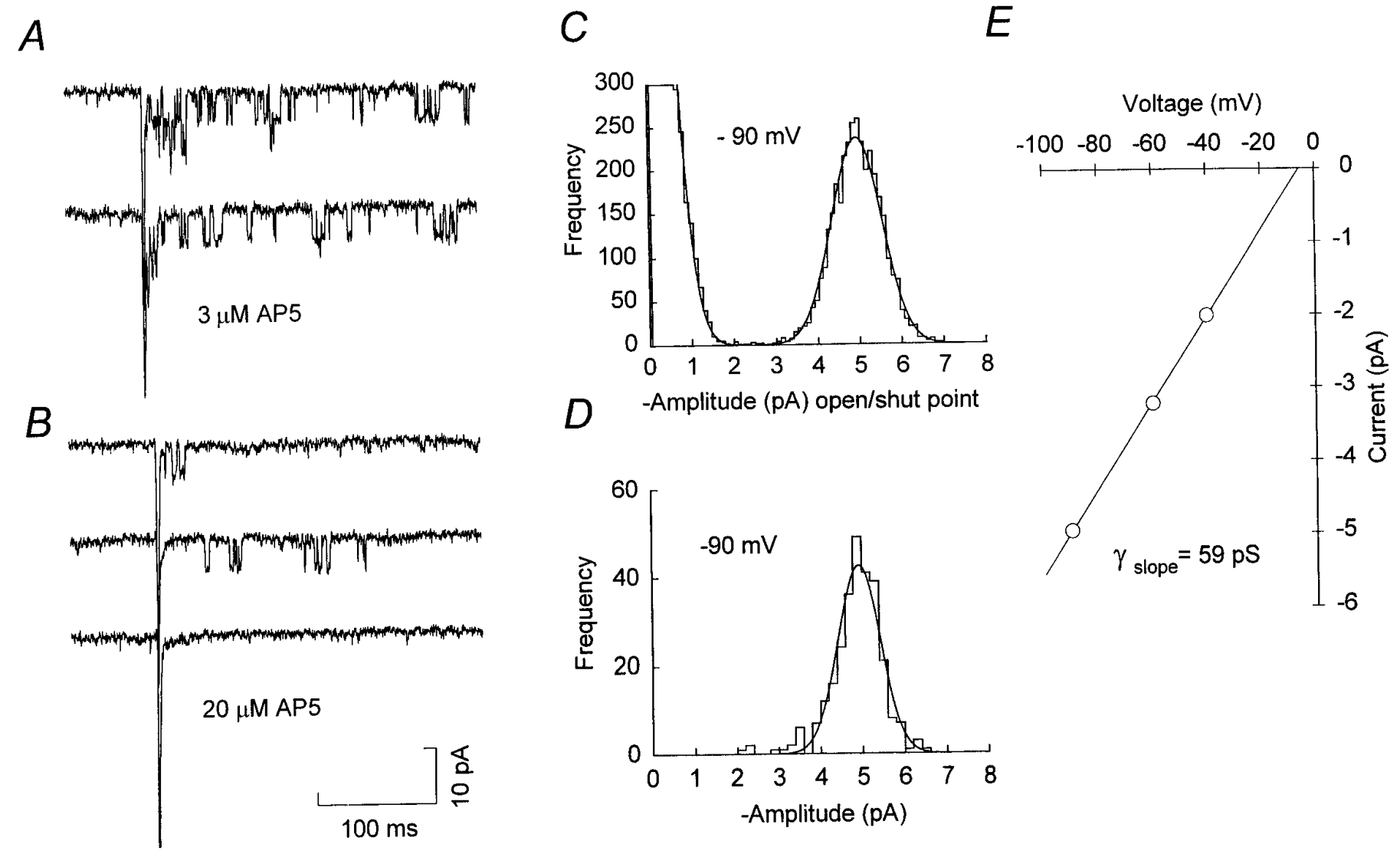

Figure 2. Resolution of synaptic NMDA channel openings. $A$, Representative evoked EPSCs recorded in the presence of $3 \mu \mathrm{M}$ AP5 (P12; $-90 \mathrm{mV})$. In each EPSC, the initial non-NMDA receptor-mediated component is followed by the opening of several NMDA receptor channels. $B$, Evoked EPSCs recorded in the presence of $20 \mu \mathrm{M}$ AP5 (same cell as $A$ ). Under these conditions fewer NMDA channel openings are observed, and many EPSCs consist of a fast non-NMDA component alone (bottom record). $C$, Open/shut point amplitude histogram for synaptic channels recorded at $-90 \mathrm{mV}$ in the presence of $3 \mu \mathrm{M}$ AP5. The histogram is fit by two Gaussian distributions (solid line); closed points, $0.0 \pm 0.53 \mathrm{pA}$ (mean \pm SD; truncated for display); open points, $4.96 \pm 0.60 \mathrm{pA}$. For a reversal potential of $-5.6 \mathrm{mV}$ (see $E$ ), this corresponds to a single-channel chord conductance of $58.8 \mathrm{pS}$. $D$, Histogram of cursor-measured amplitudes, fit with a single Gaussian distribution (4.92 $\pm 0.47 \mathrm{pA})$ corresponding to a single-channel chord conductance of $58.3 \mathrm{pA}$. $E$, Current-voltage relationship for synaptic channel openings from the same cell as $A-D$, recorded in the presence of $10 \mu \mathrm{M}$ AP5 (all-point amplitude measurements). The solid line is a linear regression through the data, yielding a slope conductance of $58.8 \mathrm{pS}$ and an extrapolated reversal potential of $-5.6 \mathrm{mV}$.

antagonists. The initial component was blocked reversibly by the non-NMDA receptor antagonist CNQX $(5 \mu \mathrm{M}, n=10)$, whereas the slow component could be inhibited by the NMDA receptor antagonists D-2-amino-5-phosphonopentanoic acid (AP5; $20 \mu \mathrm{M}$, $n=10$; Fig. $1 B)$ or $(+)-5$-methyl-10,11-dihydro-5H-dibenzo[ $a, d]$ cyclohepten-5,10-imine maleate (MK-801; 2-5 $\mu \mathrm{M}, n=6$ ) (Silver et al., 1992; D'Angelo et al., 1993; Traynelis et al., 1993).

In $\sim 50 \%$ of recordings it was possible to observe current steps late in the decay of evoked EPSCs, corresponding to the opening of single NMDA channels (Fig. 1A). However, during most of the EPSC decay, several NMDA channels opened simultaneously, making it difficult to measure accurately the current through single channels. To reduce the number of receptors activated and enable the resolution of individual channel openings, we made recordings in the presence of the competitive antagonist AP5 at concentrations $(3-20 \mu \mathrm{M})$ that were insufficient to block completely the NMDA component of the EPSC. The application of AP5 also eliminated the low level of spontaneous NMDA channel activity that usually occurred even in the absence of synaptic activity (Silver et al., 1992; Rossi et al., 1993; Farrant et al., 1994). Because it was not possible to assign such spontaneous activity to somatic or synaptic sites, the presence of AP5 ensured that chan- nel openings observed during stimulation could be ascribed solely to the activation of postsynaptic receptors.

Under these conditions, most evoked EPSCs consisted of a fast non-NMDA receptor-mediated component, followed by a small but variable number of discrete NMDA channel openings, which were apparent as square steps in the current record (Fig. $2 A, B$ ). In solutions containing $1 \mathrm{~mm} \mathrm{Ca}^{2+}$, the single-channel current was $\sim 5 \mathrm{pA}$ at $-90 \mathrm{mV}$, as compared with a baseline r.m.s. noise of $\sim$ $0.6 \mathrm{pA}(2 \mathrm{kHz},-3 \mathrm{~dB}$ Bessel filtering). Increasing the concentration of AP5 to $20 \mu \mathrm{M}$ (from 3 or $10 \mu \mathrm{M}$ ) further reduced the number of NMDA channel openings evoked by each stimulus (Fig. 2B), and some EPSCs consisted of the initial non-NMDA receptor-mediated component alone (Fig. $2 B$, bottom trace). The remaining NMDA channel openings occurred with variable latency from the onset of the synaptic current and tended to take place in bursts, separated by relatively long closed periods. At negative voltages, these channel openings were blocked by $1 \mathrm{~mm}$ $\mathrm{Mg}^{2+}$ (data not shown). To determine the slope conductance of the synaptic NMDA channels, we evoked EPSCs at three to five potentials between -20 and $-100 \mathrm{mV}$; all-point amplitude histograms were constructed from channel currents occurring within $300 \mathrm{msec}$ of the onset of the non-NMDA component of each 
Table 1. Properties of synaptic and extrasynaptic NMDA channels in cerebellar granule cells

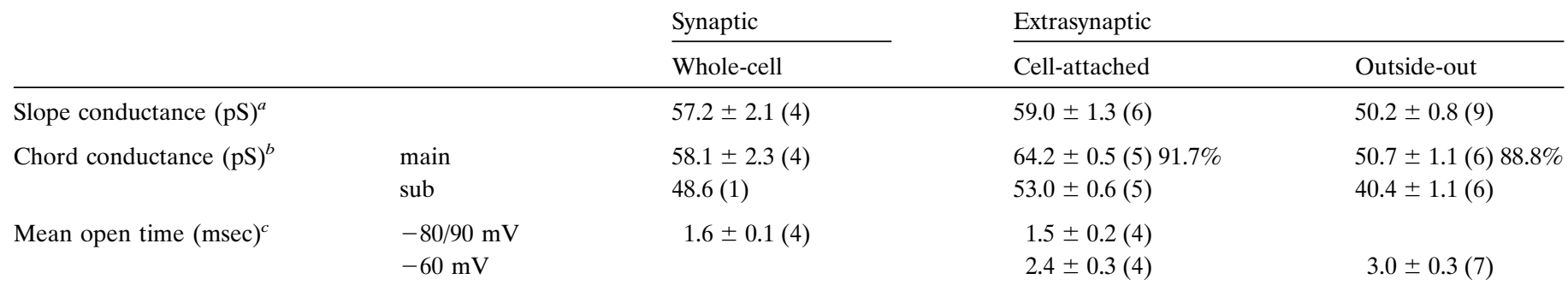

${ }^{a}$ Determined from all-point amplitude histograms obtained at 3-5 holding potentials between -20 and $-100 \mathrm{mV}$.

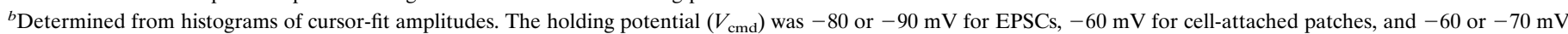
for outside-out patches. Where subconductance states were present, the mean percentage of openings to the main state is given.

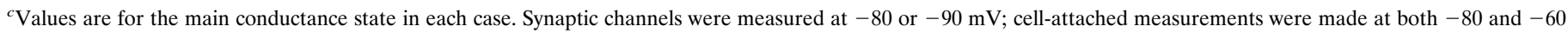
$\mathrm{mV}$; outside-out measurements were made at $-60 \mathrm{mV}$.

All values are mean \pm SEM, and numbers in parentheses indicate the number of cells or patches.

EPSC. The mean single-channel current, determined from Gaussian fits to these amplitude distributions (Fig. 2C), was plotted against voltage and the data fit by linear regression. For the example shown in Figure $2 E$, the slope conductance was $59 \mathrm{pS}$. In practice, it was necessary to select cells with very low noise levels from which sufficiently long recordings were obtained to allow channel openings to be studied over a range of potentials. From four such cells we obtained a mean slope conductance for the synaptic NMDA channels of $57.2 \pm 2.1 \mathrm{pS}\left(E_{\mathrm{rev}}=-4.4 \pm 2.3\right.$ $\mathrm{mV}$; mean $\pm \mathrm{SEM}, n=4)$. Using time course fitting (see Materials and Methods), we obtained a value of $58.1 \pm 2.3 \mathrm{pS}$ for the chord conductance of the channels at $-90 \mathrm{mV}$ (Table 1). In three of the four cells, only one conductance level could be resolved (Fig. 2D). In the fourth cell, time course fitting revealed a subconductance state of $48.6 \mathrm{pS}$. Analysis of evoked EPSCs usually began 5-10 min after establishing the whole-cell configuration, and subsequent recordings lasted from 12-60 min. During this period we did not observe any time-dependent changes in the measured single-channel conductance. The mean open time of the $60 \mathrm{pS}$ main conductance state at $-90 \mathrm{mV}$ was $1.61 \pm 0.13$ msec $(n=4)$, and distributions of open times could be fit by a single exponential with a time constant of $1.29 \pm 0.13 \mathrm{msec}(n=$ 4). Clearly, if AP5 were to alter channel kinetics or affect only certain conductance levels, this would result in erroneous estimates of synaptic channel parameters. This seems unlikely, however, because conductance and open time estimates were independent of AP5 concentration (3-20 $\mu \mathrm{M})$. Moreover, synaptic channels measured from evoked EPSCs in the presence of AP5 (in $2 \mathrm{mM} \mathrm{Ca}^{2+}$; data not shown) had a conductance similar to that measured from miniature EPSCs in the absence of AP5 (2 mM $\mathrm{Ca}^{2+}$; Silver et al., 1992).

The single-channel conductance of $\sim 60 \mathrm{pS}$ obtained in these experiments is greater than that found previously for extrasynaptic channels in outside-out patches taken from the soma of granule cells (Farrant et al., 1994) and other neurons recorded with similar extracellular $\mathrm{Ca}^{2+}$ (Nowak et al., 1984; Ascher et al., 1988; Gibb and Colquhoun, 1992; Momiyama et al., 1996). There are two possible explanations for this. First, the discrepancy could result from differences between the recording conditions used in the present and in previous studies. Second, the behavior of synaptic and extrasynaptic NMDA receptors could be different. To address the first of these possibilities, we examined the conductance of NMDA channels in excised patches.

\section{Extrasynaptic NMDA channels in outside-out membrane patches}

Figure 3 shows data obtained from somatic NMDA channels in an outside-out patch. Analysis of all-point data from nine patches gave a mean slope conductance of $50.2 \pm 0.8 \mathrm{pS}\left(E_{\mathrm{rev}}=-2.4 \pm\right.$ $1.6 \mathrm{mV})$, significantly different from that of synaptic channels $(p=0.006)$. Time course fitting was applied to openings from six of these patches. Two conductance states were resolved: a main chord conductance of $50.7 \pm 1.1 \mathrm{pS}(88.8 \pm 1.7 \%$ of all openings) and a subconductance of $40.4 \pm 1.1 \mathrm{pS}(n=6$; Table 1$)$. The mean open time of the $50 \mathrm{pS}$ main conductance state at $-60 \mathrm{mV}$ was $3.03 \pm 0.30 \mathrm{msec}(n=7)$. Distributions of open times were described either by a single exponential with a time constant of $3.07 \pm 0.40 \mathrm{msec}(n=4)$ or by two exponentials with time constants of $0.90 \pm 0.20 \mathrm{msec}(48.6 \pm 11.7 \%)$ and $3.29 \pm 0.30$ $\operatorname{msec}(n=3)$. These results are very similar to those obtained previously with intracellular solutions lacking Mg-ATP (Farrant et al., 1994) and suggest a genuine difference in the conductance of synaptic and extrasynaptic receptors. This could result from local differences in the receptor environment or the presence of distinct receptor types at these two sites. To investigate this difference, we next examined the properties of extrasynaptic channels by using cell-attached recordings designed to mimic more closely the conditions under which the synaptic channels were studied.

\section{Extrasynaptic NMDA channels in cell-attached patches}

NMDA channels in the somatic membrane were examined via a cell-attached electrode containing $1 \mu \mathrm{M}$ glutamate, $3 \mu \mathrm{M}$ glycine, $5 \mu \mathrm{M}$ CNQX, $10 \mu \mathrm{M}$ bicuculline methobromide, and $300 \mathrm{nM}$ strychnine (Fig. $4 A$ ). In cells with a high input resistance, current flow through channels in the cell-attached patch can cause significant changes in the cell membrane potential, leading to distortion of the single-channel waveform and errors in the measurement of the single-channel conductance (Fischmeister et al., 1986; Barry and Lynch, 1991). To prevent such changes in membrane voltage and allow the channel openings to be resolved, we voltageclamped the cell with a second patch electrode in the whole-cell configuration (see Fig. $4 A$ and Materials and Methods). This arrangement had the advantage that it also enabled us to dialyze the cell and thus replicate the conditions used for recording synaptic channels. Because AP5, CNQX, bicuculline, and TTX were present in the external solution, the only channels activated were those in the patch of somatic membrane beneath the cellattached electrode. Figure $4, B$ and $C$, shows extrasynaptic single- 
A

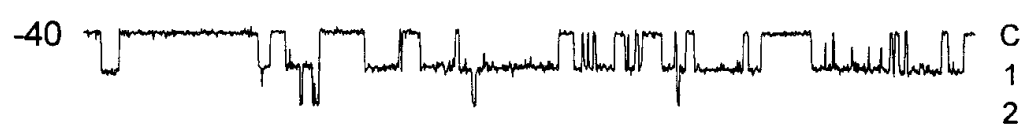

$-60$

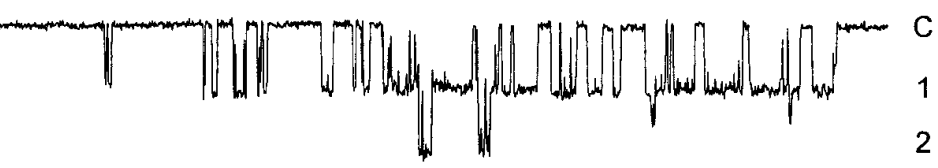

$-80$

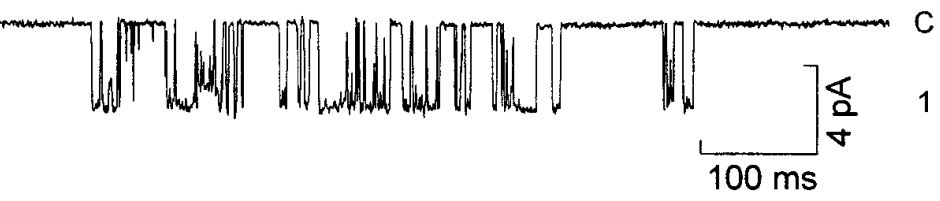

$B$

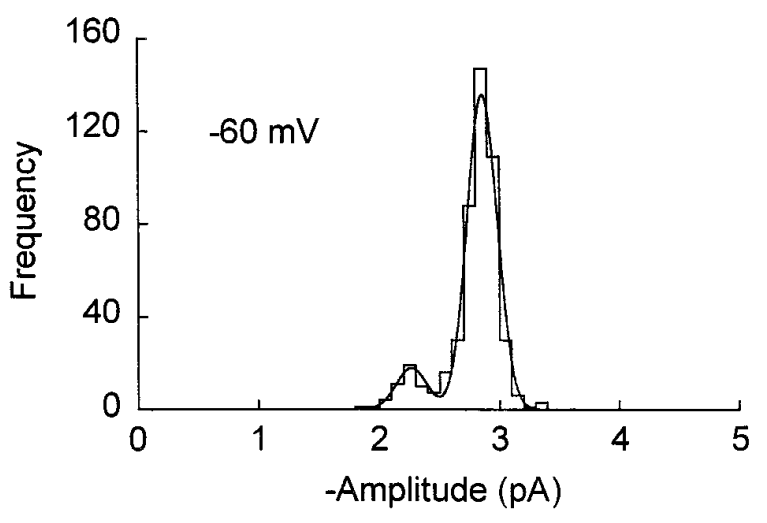

C

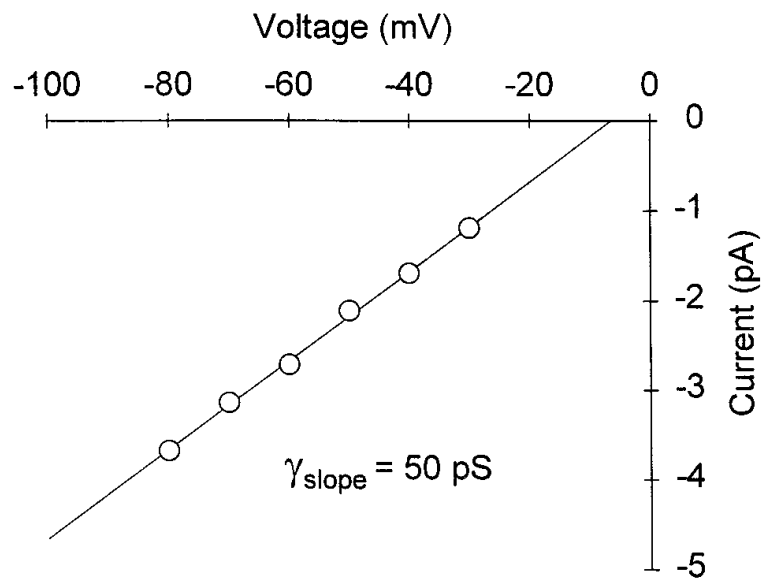

Figure 3. Extrasynaptic NMDA channels in outsideout patches. $A$, Single-channel records from an outsideout patch taken from the soma of a P12 granule cell $\left(V_{\text {cmd }}=-80,-60\right.$, and $\left.-40 \mathrm{mV}\right)$. Inward currents in response to bath application of $1 \mu \mathrm{M}$ glutamate and 3 $\mu \mathrm{M}$ glycine indicate the opening of 1 or 2 channels from the closed level $(C)$. $B$, Histogram of cursor-fit channel amplitudes at $-60 \mathrm{mV}$. The data are fit by two Gaussian distributions (solid line) with the current levels of $-2.86 \pm 0.13(88.7 \%)$ and $-2.27 \pm 0.13 \mathrm{pA}$ (mean \pm $\mathrm{SD})$. For a reversal potential of $-6.4 \mathrm{mV}$ (see $C$ ), this corresponds to single-channel chord conductances of 53.3 and $42.3 \mathrm{pS}$. $C$, Current-voltage relationship for channel openings from the same cell as $A$ and $B$ (allpoint amplitude measurements). The solid line is a linear regression through the data, yielding a slope conductance of $49.7 \mathrm{pS}$ and an extrapolated reversal potential of $-6.4 \mathrm{mV}$. channel currents recorded with this approach. In each paired record the top trace was from the cell-attached electrode, and the channel openings are upward; the bottom trace shows the same extrasynaptic channel openings recorded simultaneously at the whole-cell electrode, where the record is noisier because of the larger membrane area.

To determine the unitary conductance of the extrasynaptic channels, we recorded openings from the cell-attached patch at various potentials set by the whole-cell electrode (Fig. $5 A$ ). Recordings with resolvable channel openings were obtained from 31 cells. Channel conductances were determined from six of these recordings in which it was possible to obtain measurements over a range of voltages. The mean slope conductance of the extrasynaptic NMDA channels determined from distributions of all-point amplitudes was $59.0 \pm 1.3 \mathrm{pS}\left(E_{\mathrm{rev}}=2.2 \pm 2.0 \mathrm{mV}, n=6\right)$, significantly different from that seen with excised patches $(p=$ $0.0003)$ but not different from the conductance of synaptic channels $(p=0.48)$. Time course fitting revealed the presence of two conductance states (Fig. $5 B$ ): a main chord conductance of $64.2 \pm$ $0.5 \mathrm{pS}(91.7 \pm 0.5 \%$ of openings) and a subconductance of $53.0 \pm$ $0.6 \mathrm{pS}(n=6$; Table 1$)$. These data demonstrate that, when recorded in the "intact" cell as opposed to excised patches, the conductance of extrasynaptic channels corresponds to that of synaptic channels. 


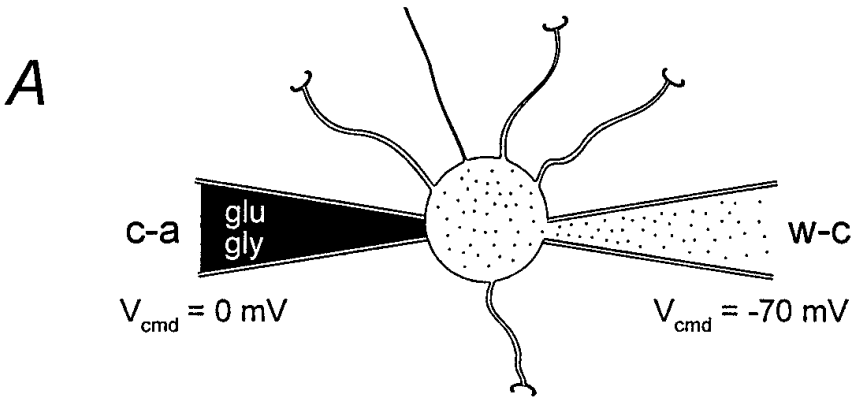

TTX, AP5, CNQX, bicuculline, strychnine
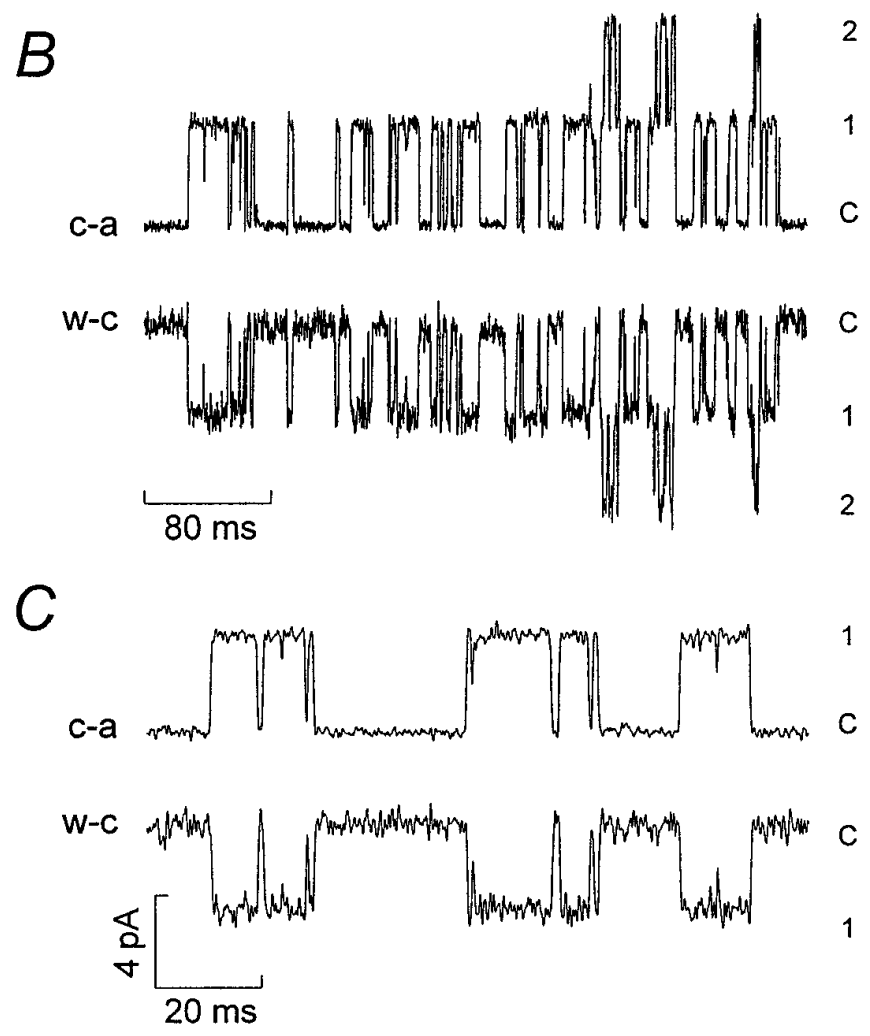

Figure 4. Isolation of extrasynaptic NMDA channel openings. $A$, Diagram showing the approach used to record selectively somatic NMDA channel openings. A granule cell with four dendrites and an axon is shown with cell-attached $(c-a)$ and whole-cell $(w-c)$ electrodes positioned on the soma. The diagram is not to scale; the mean soma diameter of granule cells (P9-P14) is $\sim 7 \mu \mathrm{m}$, and the dendrite length is $\sim 13 \mu \mathrm{m}$ (M. Farrant, unpublished data; see also Silver et al., 1992). B, Paired current records from a single granule cell (P12). The top trace is from the cell-attached $(c-a)$ electrode $\left(V_{\mathrm{cmd}}=0 \mathrm{mV}\right)$ with outward currents indicating the opening of 1 or 2 channels from the closed level $(C)$. The patch electrode contained $1 \mu \mathrm{M}$ glutamate, $3 \mu \mathrm{M}$ glycine, $10 \mu \mathrm{M}$ bicuculline methobromide, $5 \mu \mathrm{M}$ CNQX, and $200 \mathrm{nM}$ strychnine. The bottom trace is from the whole-cell $(w-c)$ electrode $\left(V_{\mathrm{cmd}}=-70 \mathrm{mV}\right)$, with inward currents mirroring those recorded from the cell-attached electrode. The bath solution contained $10 \mu \mathrm{M}$ bicuculline methobromide, $5 \mu \mathrm{M}$ CNQX, $10 \mu \mathrm{M}$ AP5, 200 nM strychnine, and $300 \mathrm{nM}$ TTX. $C$, Currents from the same cell as $B$, shown on a faster time course. The current scale bar applies to both $B$ and $C$. For display, the currents were digitized at $10 \mathrm{kHz}$ after filtering at $1 \mathrm{kHz}$ (8-pole Bessel, -3 dB).

For extrasynaptic channels in cell-attached patches, the mean open time of the main conductance state at $-80 \mathrm{mV}$ was $1.49 \pm$ 0.24 msec $(n=4)$, similar to that of synaptic channels. Distributions of open times were described by a single exponential, with a time constant of $1.18 \pm 0.24 \mathrm{msec}(n=4)$. At $-60 \mathrm{mV}$ the mean open time was $2.43 \pm 0.30 \mathrm{msec}(n=4)$, and distributions of open times were described by a two exponentials with time constants of $0.96 \pm 0.35 \mathrm{msec}(46.0 \pm 11.9 \%)$ and $2.79 \pm 0.68 \mathrm{msec}(n=3)$. In one cell the distribution was described best by a single exponential with a time constant of $2.42 \mathrm{msec}$. The reduction in mean open time with hyperpolarization most likely reflects the presence of some residual $\mathrm{Mg}^{2+}$ (Gibb and Colquhoun, 1992). Given the different agonist concentration profiles experienced by synaptic and extrasynaptic channels in these studies, open times might be expected to differ between the two channel populations. For example, activations observed during exposure to a low concentration of glutamate could reflect the opening of monoliganded channels, whereas openings observed after brief exposure to a high concentration of glutamate, as occurs during the EPSC, may arise from multiliganded receptors (Edmonds et al., 1992; Dzubay and Jahr, 1996). Nevertheless, there was no apparent difference in the open times of synaptic and extrasynaptic channels (Table 1). Although it is clear that marked differences exist between the open probability of NMDA channels in excised patches and in whole-cell recording (Rosenmund et al., 1993b, 1995), we did not examine more complex kinetic behavior such as closed times, burst structure, or open probability because of the uncertainties resulting from less than ideal resolution of synaptic channel openings and differences in glutamate concentration waveform.

Overall, our findings suggest that, rather than synaptic and extrasynaptic channels having different conductances, there is a change in NMDA channel conductance after patch excision. It is possible to envisage several mechanisms that could bring about this change. For example, earlier studies have linked changes in the desensitization of NMDA receptors after patch formation (Sather et al., 1990, 1992; Lester et al., 1993) to receptor dephosphorylation, triggered by a transient elevation of intracellular $\mathrm{Ca}^{2+}$ after its release from intracellular stores. To address this possibility, we recorded NMDA channels in the outside-out patch configuration while buffering intracellular $\mathrm{Ca}^{2+}$ more rapidly, replacing EGTA in the pipette solution with BAPTA (10 mm; see Materials and Methods) and including dantrolene $(20 \mu \mathrm{M})$ to block $\mathrm{Ca}^{2+}$ release from intracellular stores (Desmedt and Hainaut, 1977). Under these conditions the all-point slope conductance of NMDA channels $(54.7 \pm 1.1 \mathrm{pS}, n=5)$ was slightly, but significantly, greater than that seen with EGTA $(p=0.01)$, although still less than that seen in cell-attached recordings. In contrast, BAPTA alone failed to prevent the change in channel conductance after patch excision (slope conductance $51.1 \pm 0.6$ $\mathrm{pS}, n=5 ; p=0.58)$. $\mathrm{Ca}^{2+}$-dependent inactivation of the NMDA channel, seen in whole-cell recordings (Legendre et al., 1993; Rosenmund and Westbrook, 1993a), has been linked to $\mathrm{Ca}^{2+}$. induced depolymerization of the actin cytoskeleton, the integrity of which is necessary for normal channel function (Rosenmund and Westbrook, 1993b). In the process of making an outside-out patch, the gradual withdrawal of the pipette from the cell surface invariably leads to the formation of a strand of membrane between the pipette tip and the soma. In our experiments this frequently reached lengths of $50 \mu \mathrm{m}$ or more before the patch formed. Such deformation might well be expected to disrupt structural elements within the membrane. In an attempt to prevent this, we included phalloidin $(1 \mu \mathrm{M})$ in the pipette solution to stabilize actin filaments (Cooper, 1987). In the presence of phalloidin the channel slope conductance $(55.1 \pm 1.2 \mathrm{pS}, n=4)$ was significantly greater than that seen in control recordings $(p=$ 0.009 ) and no longer significantly different from the conductance 


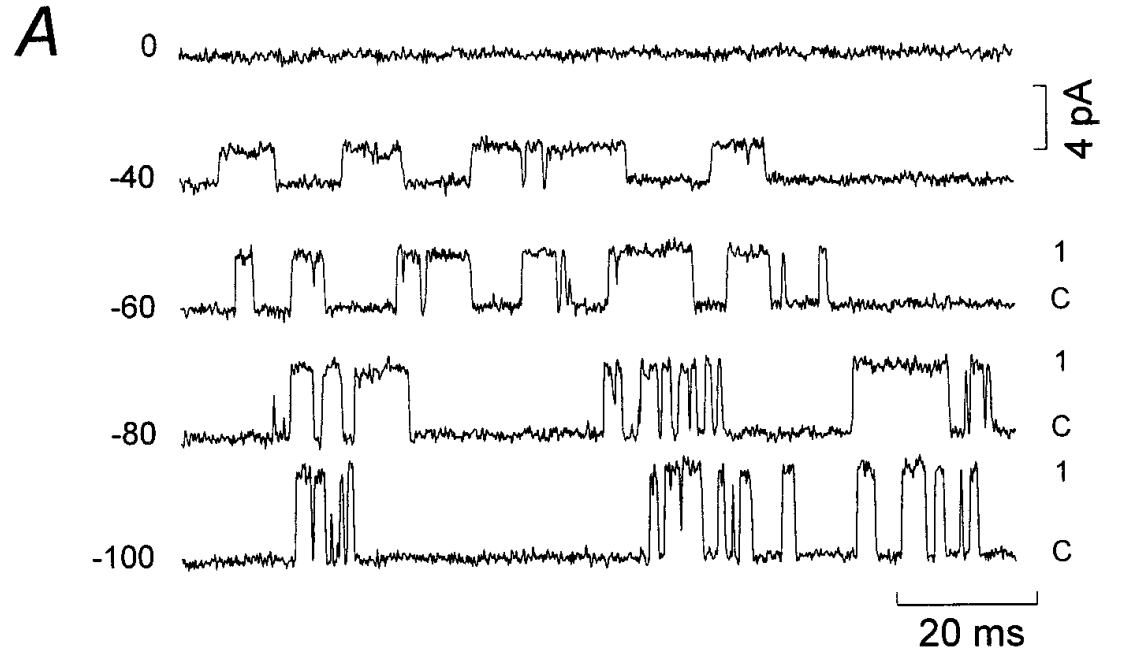

$B$
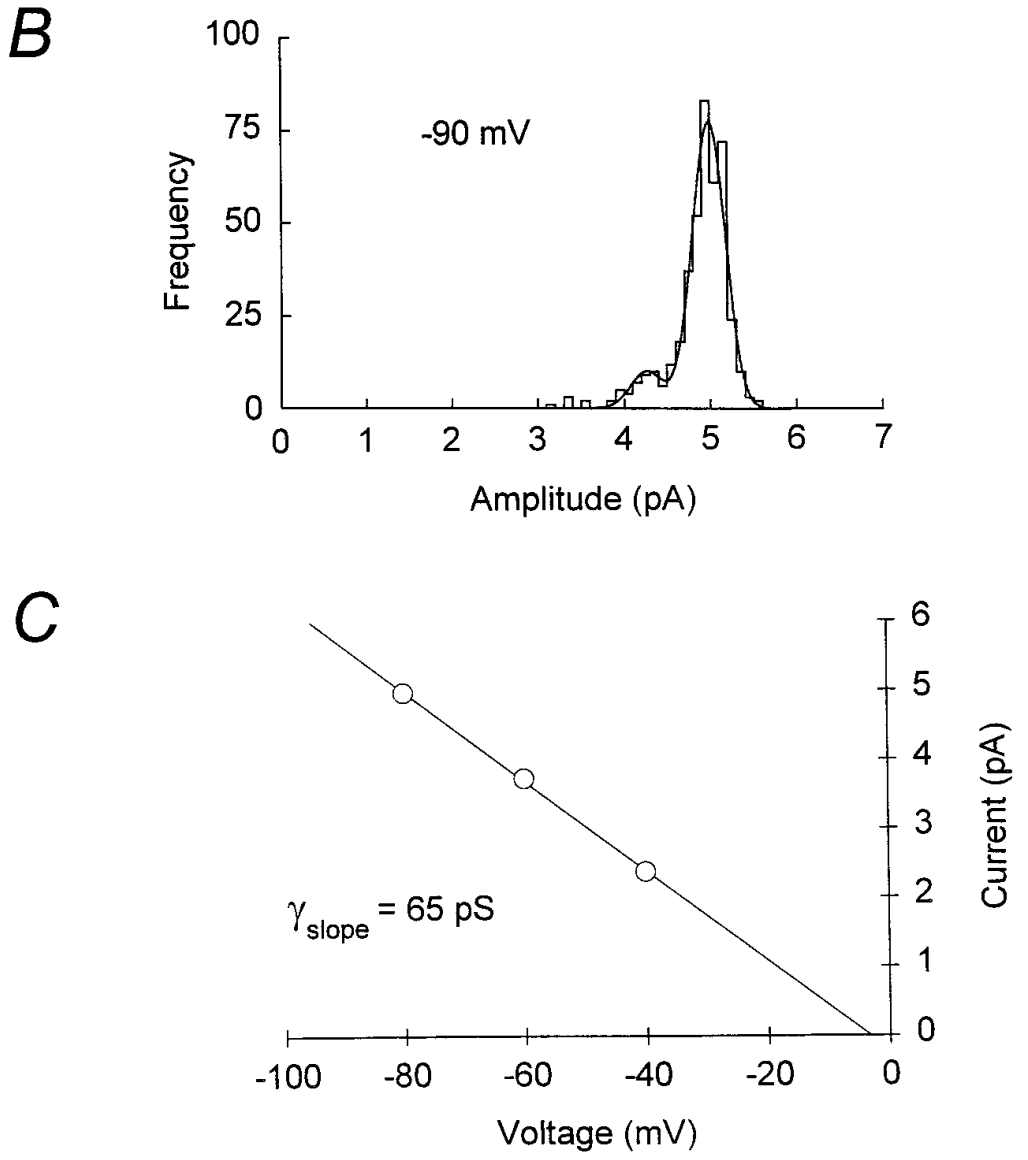

Figure 5. Determination of extrasynaptic NMDA channel conductance. $A$, Recordings of somatic NMDA channels in a P12 granule cell obtained with a cellattached electrode $\left(V_{\mathrm{cmd}}=0 \mathrm{mV}\right)$ at various potentials set by a whole-cell electrode $\left(V_{\text {cmd }}=-100,-80,-60\right.$, -40 , and $0 \mathrm{mV}$ ). The recording conditions were as described in Figure 4. Currents were digitized at $10 \mathrm{kHz}$ after filtering at $1 \mathrm{kHz}$ (8-pole Bessel, $-3 \mathrm{~dB}$ ). $B$, Histogram of cursor-fit channel amplitudes at $-80 \mathrm{mV}$ (different cell), fit by two Gaussian distributions (solid line) with the main current level being $-4.98 \pm 0.19 \mathrm{pA}$ (mean $\pm \mathrm{SD}$ ). $C$, Current-voltage relationship for the main conductance level shown in $B$. The solid line is a linear regression through the data, yielding a slope conductance of $65.0 \mathrm{pS}$ and an extrapolated reversal potential of $-3.1 \mathrm{mV}$. All-point amplitude data (not shown) gave a slope conductance of $63.5 \mathrm{pS}$ and an extrapolated reversal potential of $-3.7 \mathrm{mV}$. measured in the cell-attached configuration $(p=0.10)$. The results of these experiments are summarized in Figure 6 and suggest that the change in conductance after patch excision could be, in part at least, dependent on the release of $\mathrm{Ca}^{2+}$ from intracellular stores during patch formation and may be related to the depolymerization of actin. The mechanism of this effect is not known, but it does not seem to involve an obvious change in $\mathrm{Ca}^{2+}$ sensitivity. The conductance of synaptic channels recorded in the whole-cell configuration was dependent on the external $\mathrm{Ca}^{2+}$ concentration, as observed in recordings from excised patches (Jahr and Stevens, 1993; Premkumar and Auerbach, 1996). Thus, in the presence of $2 \mathrm{~mm}$, instead of $1 \mathrm{~mm}, \mathrm{Ca}^{2+}$ the conductance of synaptic channels was reduced by $\sim 20 \%$ (data not shown) (also see Silver et al., 1992).

\section{DISCUSSION}

The assumption that synaptic and extrasynaptic glutamate receptors are similar is implicit in many studies that have used the behavior of channels in excised patches to investigate synaptic mechanisms. The results presented here demonstrate that extrasynaptic NMDA receptors do, indeed, have conductances and open times that are very similar to those of receptors at the synapse. However, our data also reveal that granule cell NMDA channels in situ have a conductance that is $\sim 20 \%$ 


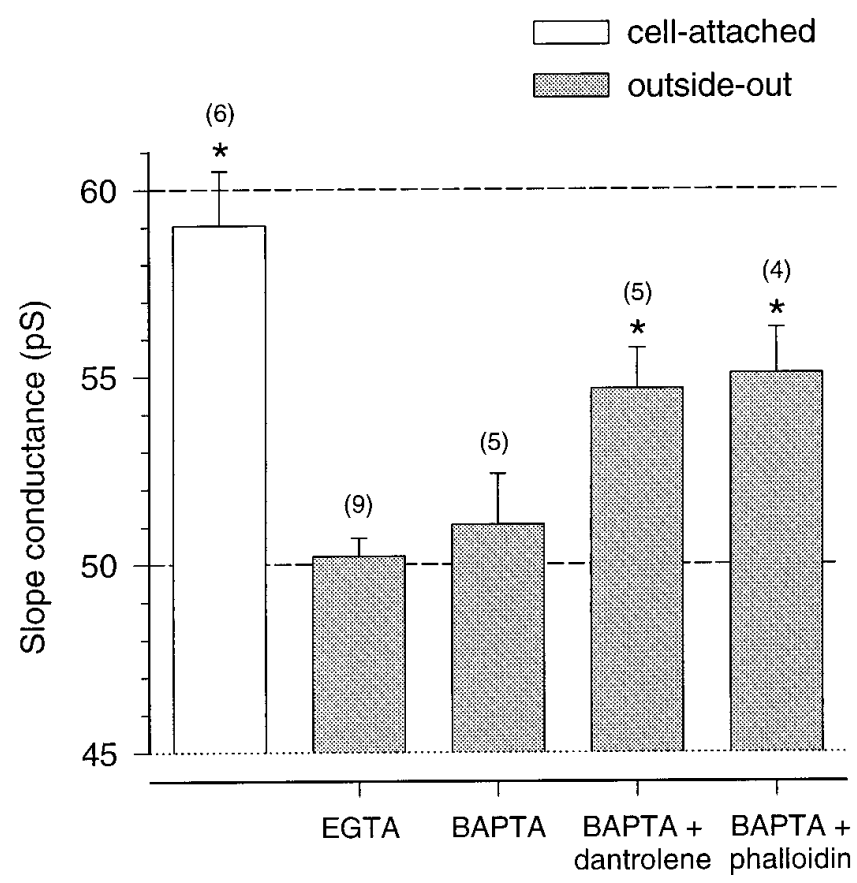

Figure 6. Slope conductance of extrasynaptic NMDA channels recorded under different conditions. A histogram of pooled data shows slope conductance for extrasynaptic NMDA channels. The open column shows the data from cell-attached patches; the filled columns show data from outside-out patches with different pipette solutions. Vertical bars indicate SEM, and numbers in parentheses indicate the number of patches recorded. The asterisks indicate a significant difference $(p<0.05)$ from the value obtained for outside-out patches recorded with a normal EGTAcontaining intracellular solution. The dashed lines at conductances of 50 and $60 \mathrm{pS}$ are drawn to facilitate comparison.

greater than that of extrasynaptic channels in patches excised from these and other central neurons. This reduction in NMDA channel conductance after patch excision can be partially prevented by block of $\mathrm{Ca}^{2+}$ release from intracellular stores by dantrolene or promotion of actin filament polymerization by phalloidin. Thus, although our studies provide support for the comparison of synaptic and extrasynaptic channels, this is qualified by the need for caution in relating results from outside-out patches to the behavior of channels in situ (see below).

\section{Comparison with previous results}

Although the conductance of synaptic NMDA channels has been examined previously and suggested to be similar to that of extrasynaptic channels (Robinson et al., 1991; Silver et al., 1992), these studies have been difficult to interpret, because their conclusions were reached mainly on the basis of comparisons among data obtained under different recording conditions. Moreover, identical conductance estimates of $48 \mathrm{pS}$ were obtained for synaptic channels in cultured hippocampal cells (Robinson et al., 1991) and cerebellar granule cells (Silver et al., 1992), despite the fact that experiments were performed with different concentrations of extracellular $\mathrm{Ca}^{2+}$, which would be expected to give rise to NMDA channel conductances that differed markedly (Ascher and Nowak, 1988; Gibb and Colquhoun, 1992; Jahr and Stevens, 1993; Premkumar and Auerbach, 1996). Notably, however, in the case of cerebellar granule cells, the conductance estimate of $\sim 50 \mathrm{pS}$ for synaptic channels obtained in $2 \mathrm{mM} \mathrm{Ca}^{2+}$ (Silver et al., 1992) is consistent with our measurement of $\sim 60 \mathrm{pS}$ in $1 \mathrm{mM} \mathrm{Ca}^{2+}$, given the predicted effect on channel conductance of such a change in $\mathrm{Ca}^{2+}$ concentration (Jahr and Stevens, 1993). This supports our finding that the single-channel conductance of NMDA receptors in intact granule cells is larger than previously thought from experiments on isolated patches. In a very recent study of NMDA receptors in granule cells from mice lacking the $\epsilon 3$ (NR2C) gene (Ebralidze et al., 1996), no difference was observed between the conductance of synaptic channels (41 pS) and those in outside-out patches (42 pS). Direct comparison of these results with our own is difficult, given the different recording conditions. However, the use of a higher external $\mathrm{Ca}^{2+}$ concentration (2.4 vs $1 \mathrm{~mm})$ and a lower intracellular concentration of EGTA (0.1 vs $5 \mathrm{~mm}$ ) could have allowed $\mathrm{Ca}^{2+}$-induced changes, which were apparent only after patch excision in our studies, to proceed in the whole-cell configuration. It is also interesting to note that these authors observed a much greater spectrum of conductances than seen in other studies.

Recently, Spruston et al. (1995) sought to determine the properties of synaptic glutamate receptors by examining channels in patches excised from regions of dendritic membrane known to receive synaptic connections. Our findings provide direct support for the proposal of these authors that synaptic NMDA receptors closely resemble those in extrasynaptic membrane, at least when these are examined under similar recording conditions. Furthermore, our conclusions drawn from studies of microscopic channel properties support those drawn from studies on the macroscopic properties of NMDA-mediated synaptic currents, which have addressed the $\mathrm{Mg}^{2+}$ sensitivity (Bekkers and Stevens, 1993), $\mathrm{Ca}^{2+}$ permeability (Jahr and Stevens, 1993), and open probability (Rosenmund et al., 1995) of the underlying channels.

\section{Molecular and developmental considerations}

At present it is not possible to say with certainty that the functional similarity between synaptic and extrasynaptic channels reflects molecular identity. Multiple NMDA receptor subunits have been identified-NR1 and NR2A, B, C, and D, plus splice variants (for review, see McBain and Mayer, 1994) - but only a few of the possible subunit combinations have been studied at the singlechannel level. Recombinant NMDA receptors formed from NR1 and NR2 subunit pairs have different properties (McBain and Mayer, 1994; Cull-Candy et al., 1995), but not all of these recombinant receptors can be distinguished on the basis of their singlechannel characteristics. Thus, channels with properties similar to those seen in the present study can be formed by coexpression of NR1 with either NR2A or NR2B subunits (Stern et al., 1992). Although NR2B is expressed primarily during embryonic development and NR2A only postnatally, at the age we have studied both subunits may be expected to be present in granule cells (Akazawa et al., 1994; Monyer et al., 1994; Watanabe et al., 1994).

The most striking change in subunit mRNA expression during cerebellar development is the pronounced postnatal increase in that for NR2C in granule cells (Akazawa et al., 1994; Monyer et al., 1994; Watanabe et al., 1994). We previously have demonstrated corresponding changes in the single-channel properties of extrasynaptic NMDA receptors during granule cell development (Farrant et al., 1994). Thus, channels in outside-out patches from young granule cells are of a "high-conductance" type (50/40 pS), whereas in more mature cells a "low-conductance" (33/20 pS) channel with properties very similar to those of NR1/NR2C recombinant receptors (Stern et al., 1992) is also present. Between P10 and P16 $>98 \%$ of outside-out patches contain only 50/40 pS channels (Farrant et al., 1994; M. Farrant, B. A. Clark, D. Feld- 
meyer, S. G. Cull-Candy, unpublished observations; this study), but between P19 and P23 most patches (65\%) also exhibit lowconductance openings (Farrant et al., 1994). Recently, similar observations have been made for cerebellar granule cells in developing mice (Takahashi et al., 1996). In the present study, a comparable situation was seen for synaptic channels and extrasynaptic channels in cell-attached patches; in none of the recordings did we observe low-conductance channel openings. Thus, we have no evidence for the expression of low-conductance (NR1/ NR2C) channels in either extrasynaptic or synaptic membrane at the age we have studied here (P12-P13). Although NR2C mRNA is clearly present at this time, it is possible that the NR2C protein is not. This could occur, for example, if NMDA receptor expression were governed by factors affecting mRNA translation and/or post-translational events (Resink et al., 1995; Wood et al., 1996). Alternatively, our results could be explained if there were preferential assembly of receptors containing more than one type of NR2 subunit (Sheng et al., 1994) yielding channels with a high conductance. The coassembly of NR1, NR2A, and NR2C subunits has been suggested to occur after coexpression in Xenopus oocytes (Wafford et al., 1993) or HEK 293 cells (Chazot et al., 1994), but as yet nothing is known of the single-channel properties of such assemblies.

Given the developmental changes in somatic NMDA receptors (Farrant et al., 1994), it is possible that synaptic and extrasynaptic NMDA channels could differ in the adult. However, in the visual cortex, developmental changes in the kinetic properties of extrasynaptic NMDA receptors are mirrored by changes in the properties of NMDA receptor-mediated EPSCs (Carmignoto and Vicini, 1992), and it seems likely, therefore, that any developmental changes affect all receptors uniformly, irrespective of their location in the membrane. A similar situation has been described most clearly for nicotinic acetylcholine receptors in innervated muscle (Brehm and Kullberg, 1987). Consistent with this view, recent experiments on $\epsilon 1$ (NR2A) subunit-ablated mutant mice indicate that, at later stages of development, $\epsilon 3$-containing (NR2C-containing) receptors are present in both synaptic and extrasynaptic membrane (see also Ebralidze et al., 1996; Takahashi et al., 1996).

\section{The effect of patch excision}

The finding that NMDA channels recorded in excised patches differ in conductance from those recorded in intact cells (whole-cell or cell-attached recording) was unexpected. However, other properties of NMDA receptors, including their glycine-sensitive desensitization (Sather et al., 1992; Lester et al., 1993), mechanosensitivity (Paoletti and Ascher, 1994), and open probability $\left(P_{\mathrm{o}}\right.$; Rosenmund et al., 1995), have been found to be dependent on recording configuration. In the latter case, estimates of synaptic channel $P_{\mathrm{o}}$ are much lower than for extrasynaptic channels in excised patches. Because the $P_{\mathrm{o}}$ of both synaptic and extrasynaptic receptors recorded in the whole-cell configuration was low, the higher $P_{\mathrm{o}}$ in patches was ascribed to the loss of cytoplasmic factors (Rosenmund et al., 1995). Our experiments suggest that an interaction with the actin cytoskeleton or associated proteins, analogous to that implicated in the $\mathrm{Ca}^{2+}$-dependent rundown of the NMDA response in cultured neurons (Rosenmund and Westbrook, 1993b), may subtly affect the conductance of NMDA receptors. NMDA receptors seem subject to direct and indirect modulation by a number of intracellular proteins, including phosphorylation and dephosphorylation by $\mathrm{Ca}^{2+}$-dependent and $\mathrm{Ca}^{2+}$ - independent kinases and phosphatases (Chen and Huang, 1991, 1992; Lieberman and Mody, 1994; Wang and Salter, 1994; Tong et al., 1995; Köhr and Seeburg, 1996; Raman et al., 1996; Wang et al., 1996) and interaction with calmodulin (Ehlers et al., 1996). Although none of these processes has been shown to affect NMDA channel conductance, it is of note that the conductance of another ligand-gated cation channel, the $5-\mathrm{HT}_{3}$ receptor, is also reduced after formation of an outside-out patch and that this is suggested to involve receptor dephosphorylation (van Hooft and Vijverberg, 1995). Whatever the precise explanation for this aspect of our findings, it reinforces the idea that patch formation can disrupt the normal function of NMDA channels.

\section{REFERENCES}

Akazawa C, Shigemoto R, Bessho Y, Nakanishi S, Mizuno N (1994) Differential expression of five $N$-methyl-D-aspartate receptor subunit mRNAs in the cerebellum of developing and adult rats. J Comp Neurol 347:150-160.

Ascher P, Nowak L (1988) The role of divalent cations in the $N$-methylD-aspartate responses of mouse central neurones in culture. J Physiol (Lond) 399:247-266.

Ascher P, Bregestovski P, Nowak L (1988) N-Methyl-D-aspartateactivated channels of mouse central neurones in magnesium-free solutions. J Physiol (Lond) 399:207-266.

Barry PH, Lynch JW (1991) Liquid junction potentials and small cell effects in patch-clamp analysis. J Membr Biol 121:101-117.

Bekkers JM, Stevens CF (1993) NMDA receptors at excitatory synapses in the hippocampus: test of a theory of magnesium block. Neurosci Lett 156:73-77.

Brehm P, Kullberg R (1987) Acetylcholine receptor channels on adult mouse skeletal muscle are functionally identical in synaptic and nonsynaptic membrane. Proc Natl Acad Sci USA 84:2550-2554.

Carmignoto G, Vicini S (1992) Activity-dependent decrease in NMDA receptor responses during development of the visual cortex. Science 258:1007-1011.

Chazot PL, Coleman SK, Cik M, Stephenson FA (1994) Molecular characterization of $N$-methyl-D-aspartate receptors expressed in mammalian cells yields evidence for the coexistence of three subunit types within a discrete receptor molecule. J Biol Chem 269:24403-24409.

Chen L, Huang L-YM (1991) Sustained potentiation of NMDA receptor-mediated glutamate responses through activation of protein kinase $C$ by a $\mu$ opioid. Neuron 7:319-326.

Chen L, Huang L-YM (1992) Protein kinase C reduces $\mathrm{Mg}^{2+}$ block of NMDA-receptor channels as a mechanism of modulation. Nature 356:521-523.

Colquhoun D (1971) Lectures on biostatistics. Oxford: Clarendon.

Colquhoun D, Sigworth FJ (1995) Fitting and statistical analysis of single-channel records. In: Single-channel recording, 2nd Ed (Sakmann B, Neher E, eds), pp 483-587. New York: Plenum.

Cooper JA (1987) Effects of cytochalasin and phalloidin on actin. J Cell Biol 105:1473-1478.

Cull-Candy SG, Farrant M, Feldmeyer D (1995) NMDA channel conductance: a user's guide. In: Excitatory amino acids and synaptic transmission, 2nd Ed (Wheal H, Thomson A, eds), pp 121-132. London: Academic.

D'Angelo E, Rossi P, Taglietti V (1993) Different proportions of $N$-methyl-D-aspartate and non- $N$-methyl-D-aspartate receptor currents at the mossy fibre-granule cell synapse of developing rat cerebellum. Neuroscience 53:121-130.

Desmedt JE, Hainaut K (1977) Inhibition of the intracellular release of calcium by dantrolene in barnacle giant muscle fibres. $\mathrm{J}$ Physiol (Lond) 265:565-585.

Dzubay JA, Jahr CE (1996) Kinetics of NMDA channel opening. J Neurosci 16:4129-4134.

Ebralidze AK, Rossi DJ, Tonegawa S, Slater NT (1996) Modification of NMDA receptor channels and synaptic transmission by targeted disruption on the NR2C gene. J Neurosci 16:5014-5025.

Edmonds B, Colquhoun D (1992) Rapid decay of averaged singlechannel NMDA receptor activations recorded at low agonist concentration. Proc R Soc Lond [Biol] 250:279-286. 
Edmonds B, Gibb AJ, Colquhoun D (1995) Mechanisms of activation of glutamate receptors and the time course of excitatory synaptic currents. Annu Rev Physiol 57:495-519.

Ehlers MD, Tingley WG, Huganir RL (1995) Regulated subcellular distribution of the NR1 subunit of the NMDA receptor. Science 269:1734-1737.

Ehlers MD, Zhang S, Bernhardt JP, Huganir RL (1996) Inactivation of NMDA receptors by direct interaction of calmodulin with the NR1 subunit. Cell 84:745-755.

Farrant M, Cull-Candy SG (1991) Excitatory amino acid receptorchannels in Purkinje cells in thin cerebellar slices. Proc R Soc Lond [Biol] 244:179-184.

Farrant M, Feldmeyer D, Takahashi T, Cull-Candy SG (1994) NMDAreceptor channel diversity in the developing cerebellum. Nature 368:335-339.

Fischmeister R, Ayer Jr RK, DeHaan RL (1986) Some limitations of the cell-attached patch-clamp technique: a two-electrode analysis. Pflügers Arch 406:73-82.

Gibb AJ, Colquhoun D (1992) Activation of $N$-methyl-D-aspartate receptors by L-glutamate in cells dissociated from adult rat hippocampus. J Physiol (Lond) 456:143-179.

Hamill OP, Marty A, Neher E, Sakmann B, Sigworth FJ (1981) Improved patch-clamp techniques for high-resolution current recording from cells and cell-free membrane patches. Pflügers Arch 391:85-100.

Howe JR, Cull-Candy SG, Colquhoun D (1991) Currents through single glutamate receptor channels in outside-out patches from cerebellar granule cells. J Physiol (Lond) 432:143-202.

Jahr CE, Stevens CF (1993) Calcium permeability of the $N$-methyl-Daspartate receptor channel in hippocampal neurons in culture. Proc Natl Acad Sci USA 90:11573-11577.

Johnson JW, Ascher P (1987) Glycine potentiates the NMDA response in cultured mouse brain neurons. Nature 325:529-531.

Kaneda M, Farrant M, Cull-Candy SG (1995) Whole-cell and singlechannel currents activated by GABA and glycine in granule cells of the rat cerebellum. J Physiol (Lond) 485:419-435.

Köhr G, Seeburg PH (1996) Subtype-specific regulation of recombinant NMDA receptor-channels by protein tyrosine kinases of the src family. J Physiol (Lond) 492:445-452.

Kornau HC, Schenker LT, Kennedy MB, Seeburg PH (1995) Domain interaction between NMDA receptor subunits and the postsynaptic density protein PSD-95. Science 269:1737-1740.

Legendre P, Rosenmund C, Westbrook GL (1993) Inactivation of NMDA channels in cultured hippocampal neurons by intracellular calcium. J Neurosci 13:674-684.

Lester RA, Clements JD, Westbrook GL, Jahr CE (1990) Channel kinetics determine the time course of NMDA receptor-mediated synaptic currents. Nature 346:565-567.

Lester RA, Tong G, Jahr CE (1993) Interactions between the glycine and glutamate binding sites of the NMDA receptor. J Neurosci 13:1088-1096.

Lieberman DN, Mody I (1994) Regulation of NMDA channel function by endogenous $\mathrm{Ca}^{2+}$-dependent phosphatase. Nature 369:235-239.

McBain C, Mayer ML (1994) N-Methyl-D-aspartic acid receptor structure and function. Physiol Rev 74:723-760.

Miyashiro K, Dichter M, Eberwine J (1994) On the nature and differential distribution of mRNAs in hippocampal neurites: implications for neuronal functioning. Proc Natl Acad Sci USA 91:10800-10804.

Momiyama A, Feldmeyer D, Cull-Candy SG (1996) Identification of a native low-conductance NMDA channel with reduced sensitivity to $\mathrm{Mg}^{2+}$ in rat central neurons. J Physiol (Lond) 494:479-492.

Monyer H, Burnashev N, Laurie DJ, Sakmann B, Seeburg PH (1994) Developmental and regional expression in the rat brain and functional properties of four NMDA receptors. Neuron 12:529-540.

Niethammer M, Kim E, Sheng M (1996) Interaction between the C terminus of NMDA receptor subunits and multiple members of the PSD-95 family of membrane-associated guanylate kinases. J Neurosci 16:2157-2163.

Nowak L, Bregestovski P, Ascher P, Herbet A, Prochiantz A (1984) Magnesium gates glutamate-activated channels in mouse central neurones. Nature 307:462-465.

Paoletti P, Ascher P (1994) Mechanosensitivity of NMDA receptors in cultured mouse central neurons. Neuron 13:645-655.

Premkumar LS, Auerbach A (1996) Identification of a high affinity divalent cation binding site near the entrance of the NMDA receptor channel. Neuron 16:869-880.
Raman IM, Tong G, Jahr CE (1996) $\beta$-Adrenergic regulation of synaptic NMDA receptors by cAMP-dependent protein kinases. Neuron 16:415-421.

Resink A, Villa M, Boer GJ, Möhler H, Balázs R (1995) Agonist-induced down-regulation of NMDA receptors in cerebellar granule cells in culture. Eur J Neurosci 7:1700-1706.

Robinson HP, Sahara Y, Kawai N (1991) Nonstationary fluctuation analysis and direct resolution of single channel currents at postsynaptic sites. Biophys J 59:295-304.

Rosenmund C, Westbrook GL (1993a) Rundown of $N$-methyl-Daspartate channels during whole-cell recording in rat hippocampal neurons: role of $\mathrm{Ca}^{2+}$ and ATP. J Physiol (Lond) 470:705-729.

Rosenmund C, Westbrook GL (1993b) Calcium-induced actin depolymerization reduces NMDA channel activity. Neuron 10:805-814.

Rosenmund C, Feltz A, Westbrook GL (1995) Synaptic NMDA receptor channels have a low open probability. J Neurosci 15:2788-2795.

Rossi DJ, Slater NT (1993) The developmental onset of NMDA receptor-channel activity during neuronal migration. Neuropharmacology 32:1239-1248.

Sather W, Johnson JW, Henderson G, Ascher P (1990) Glycineinsensitive desensitization of NMDA responses in cultured mouse embryonic neurons. Neuron 4:725-731.

Sather W, Dieudonne S, MacDonald JF, Ascher, P (1992) Activation and desensitization of $N$-methyl-D-aspartate receptors in nucleated outside-out patches from mouse neurones. J Physiol (Lond) 450:643-672.

Sheng M, Cummings J, Rolda LA, Jan YN, Jan LY (1994) Changing subunit composition of heteromeric NMDA receptors during development of rat cortex. Nature 368:144-147.

Silver RA, Traynelis SF, Cull-Candy SG (1992) Rapid-time course miniature and evoked excitatory currents at cerebellar synapses in situ. Nature 355:163-166.

Spruston N, Jonas P, Sakmann B (1995) Dendritic glutamate receptor channels in rat hippocampal CA3 and CA1 pyramidal neurones. J Physiol (Lond) 482:325-352.

Stern P, Béhé P, Schoepfer R, Colquhoun D (1992) Single-channel conductances of NMDA receptors expressed from cloned cDNAs: comparison with native receptors. Proc R Soc Lond [Biol] 250:271-277.

Takahashi T, Feldmeyer D, Suzuki N, Onodera K, Cull-Candy SG, Sakimura K, Mishina M (1996) Functional correlation of NMDA receptor $\epsilon$ subunit expression with the properties of single-channel and synaptic currents in the developing cerebellum. J Neurosci 16:4376-4382.

Tong G, Jahr CE (1994) Regulation of glycine-insensitive desensitization of the NMDA receptor in outside-out patches. J Neurophysiol 72:754-761.

Tong G, Shepherd D, Jahr CE (1995) Synaptic desensitization of NMDA receptors by calcineurin. Science 267:1510-1512.

Traynelis SF, Silver RA, Cull-Candy SG (1993) Estimated conductance of glutamate receptor channels activated during EPSCs at the cerebellar mossy fiber-granule cell synapse. Neuron 11:279-289.

Tsuzuki K, Mochizuki S, Iino M, Mori H, Mishina M, Ozawa S (1994) Ion permeation properties of the cloned mouse $\epsilon 2 / \zeta 1$ NMDA receptor channel. Mol Brain Res 26:37-46.

van Hooft JA, Vijverberg PM (1995) Phosphorylation controls conductance of 5- $\mathrm{HT}_{3}$ receptor ligand-gated ion channels. Receptors Channels 3:7-12.

Wafford KA, Bain CJ, Le-Bourdelles B, Whiting PJ, Kemp JA (1993) Preferential co-assembly of recombinant NMDA receptors composed of three different subunits. NeuroReport 4:1347-1349.

Wang YT, Salter MW (1994) Regulation of NMDA receptors by tyrosine kinases and phosphatases. Nature 369:233-235.

Wang YT, Yu X-M, Salter MW (1996) $\mathrm{Ca}^{2+}$-independent reduction of $N$-methyl-D-aspartate channel activity by protein tyrosine kinase. Proc Natl Acad Sci USA 93:1721-1725.

Watanabe M, Mishina M, Inoue Y (1994) Distinct spatiotemporal expressions of five NMDA receptor channel subunit mRNAs in the cerebellum. J Comp Neurol 343:513-519.

Wood MW, VanDongen HMA, VanDongen AMJ (1996) The 5 '-untranslated region of the $N$-methyl-D-aspartate receptor NR2A subunit controls the efficiency of translation. J Biol Chem 271:8115-8120. 